\title{
Antibiogram of Bacteria Isolated from Automated Teller Machines Within Abakaliki Metropolis
}

\author{
${ }^{1}$ Okoro Nworie, ${ }^{2}$ Mbaba Mercy, \\ ${ }^{2}$ Anyim Chukwudi, ${ }^{3}$ Inya Oko, ${ }^{3}$ S. Okoli Chukwudum, \\ ${ }^{2}$ Victor Maduka Agah and ${ }^{2}$ Uchechukwu Onyeukwu Ekuma
}

\author{
${ }^{1}$ Department of Biological Sciences, \\ Faculty of Science and Technology, Federal University Ndufu Alike-Ikwo, Ebonyi State, Nigeria \\ ${ }^{2}$ Department of Applied Microbiology, Faculty of Biological Sciences, Ebonyi State University, Abakaliki, Nigeria \\ ${ }^{3}$ Department of Science Laboratory Technology, \\ School of Science and General Studies, Akanu Ibiam Federal Polytechnic Unwana, Afikpo, Nigeria
}

Received 2013-01-24, Revised 2013-02-07; Accepted 2013-02-09

\begin{abstract}
The Automated Teller Machine (ATMs) is likely to be contaminated with various microorganisms due to their vast dermal contact by multiple users. The metallic keypads of ATMs were examined to investigate their potentials as source of bacterial contamination and also the antibiogram of the isolated organisms. The study lasted from August, 2012 to October, 2012 involving several procedures like culturing, identifying the organisms using biochemical tests and Kirby Bauer disc diffusion method for antibiotic sensitivity tests. Swabs from the keypads of 20 ATMs were examined and the results indicated the contamination of the keypads with Staphylococcus aureus 9 (50\%), Klebsiella species 6 (33.3\%) and Escherichia coli 3 (16.7\%). The antibiogram were ascertained using Kirby Bauer disc diffusion method and the result showed that Staphylococcus aureus was $89 \%$ resistant to ampicillin, followed by penicillin (78\%), nalidixic acid (78\%) and augmentine $(70 \%)$, while $33 \%$ and $30 \%$ were susceptible to peflacine and gentamycin respectively. Klebsiella species were $100 \%$ resistant to erythromycin, followed by tetracycline (83\%), penicillin $(83 \%)$, ampicillin (83\%) and nalidixic acid (70\%) but showed high level susceptibility to cotrimoxazole $(65 \%)$, ciproflocacin (64\%) and augmentine (64\%). Escherichia coli were 100\% resistant to tetracycline and penicillin, followed by augmentine $(90 \%)$ and ampicilin $(85 \%)$, but $70 \%$ susceptible to ceporex, followed by peflacine $(65 \%)$ and ciprofloxacin $(65 \%)$. Hand washing and proper cleaning regimen should be practiced to reduce contamination on the ATMs.
\end{abstract}

Keywords: ATMs, Bacterial Contamination, Antibiotics Resistance, Abakaliki Metropolis

\section{INTRODUCTION}

An Automated Teller Machine or Automatic Teller Machine (ATM) is a computerized telecommunications device that enables the clients of a financial institution to perform financial transactions without the need for a cashier, human clerk or bank teller. ATMs are known by various other names including ATM machine, automated banking machine, cash dispenser and various regional variants derived from trademarks on ATM systems held by particular banks (Rasiah, 2010). A typical usage of the ATM machine involves slotting a card into a recipient hole and following on screen instructions, by punching the keys of the metallic keypads to enter secret codes and commands; thus instructing the machine as to kind of service one requires (Sharma and Anand, 2002). The ATM machine is likely to be contaminated with various microorganisms due to their vast dermal contact by multiple users.

Corresponding Author: Okoro Nworie, Department of Biological Sciences, Faculty of Science and Technology, Federal University Ndufu Alike-Ikwo, Ebonyi State, Nigeria 
Human beings have a marked tendency to pick up microorganisms from environmental objects and the hand has been shown to play a role in the transmission of organisms. Colonization of objects by pathogenic organisms has been reported as a potential vehicle for their transmission (Neely and Maley, 2000; Gerba, 2005; Famurewa and David, 2009; Ulger et al., 2009; Fraser and Girling, 2009; Gholamreza et al., 2009). Furthermore, microorganisms found to contaminate fomites have also been shown to persist on environmental surfaces for varying periods of time ranging from hours to months (French et al., 2004). Hence cross infection of microorganisms between environmental surfaces and a host has equally been established (Hardy et al., 2006).

Salmonella species and Escherichia coli have also been shown to be transferred from the hands to raw processed and cooked foods, even at low levels on the fingers (Humphrey et al., 1994; Rusin et al., 2002). Kissiedu (2002) also showed that snacks eaten with the fingers can easily be cross contaminated by bacteria from the hands after handling dirty currency notes. It has also been shown that, microbes once attached to hands and some surfaces may survive for a while and may be difficult to remove (Filho et al., 1987; Hood and Zottola, 1997).

Few works have reported on bacterial contamination of ATMs in the banks. Hence, this present study was designed to evaluate the antibiogram of bacteria present on the touched metallic keypads of ATMs within Abakaliki Metropolis and also to ascertain the possibility of cross-contaminating fingers during use of the ATMs with these bacteria which are likely to be pathogenic.

\section{MATERIALS AND METHODS}

\subsection{Study Area}

This study was conducted within the Abakaliki Metropolis in Ebonyi State. The study was undertaken from August 13th to September 10th 2012.

\subsection{Sample Collection}

Twenty Automated Teller Machines (ATMs) of eight different banks (Ecobank, Diamond Bank, Stanbic Bank, United Bank of Africa, Guarantee Trust Bank, Access Bank, Zenith Bank and Enterprise bank) situated along Ezza Road/Ogoja and Water Works Road was used for the study. Permission was sought from the management of all the banks to use the facilities. The single sterile swab sticks moistened with sterile distilled water were moved over the surfaces of the metallic keypads of ATMs. The swab sticks were immediately transported to the Microbiology laboratory complex, Ebonyi State University for microbiological analysis.

\subsection{Standardization of Test Organisms}

$0.5 \mathrm{McF}$ arland scale was used to standardize the test organisms.

\subsection{Susceptibility Testing}

The isolates were tested for antimicrobial susceptibility using Kirby Bauer agar disc diffusion method (Cheesbrough, 2006). Various antimicrobial agents used were ampicillin, cefixime, cloxacillin, cotrimoxazole, teteracycline, penicillin, gentamycin, erythromycin, nalidixic acid, tarivid, peflacine, ciprofloxacin, ceporex and augmentin. The diameter of the zones of inhibition surrounding the antimicrobial disc was measured to the nearest $\mathrm{mm}$. isolates were deemed resistant only when the zones of inhibition was less or equal to the resistance breakpoint recommended by the NCCLS (2000).

\section{RESULTS}

Four different bacteria isolates (Staphylococcus aureus, coagulase negative Staphylococcus aureus, Klebsiella species and Escherichia coli) were obtained from the Automated Teller Machines (ATMs) as shown in Table 1.

Table 2 below shows the different biochemical tests that the suspected isolates were subjected to. The isolates tested with positive or negative to oxidase, catalase, citrate, coagulase and indole test.

Table 1. Colony morphology of the isolates

\begin{tabular}{|c|c|c|c|}
\hline Isolates & $\begin{array}{l}\text { Cultural } \\
\text { characteristics }\end{array}$ & $\begin{array}{l}\text { Microscopic } \\
\text { characteristics }\end{array}$ & $\begin{array}{l}\text { Gram } \\
\text { stain }\end{array}$ \\
\hline $\begin{array}{l}\text { Staphyloco } \\
\text { ccus Aureus }\end{array}$ & $\begin{array}{l}\text { Round, smooth } \\
\text { and colonies with } \\
\text { pinkish colour on } \\
\text { raised on } \\
\text { MacConkey agar }\end{array}$ & $\begin{array}{l}\text { Cocci that forms } \\
\text { irregular clusters } \\
\text { and non-motile }\end{array}$ & Positive \\
\hline $\begin{array}{l}\text { Coagulase } \\
\text { negative }\end{array}$ & $\begin{array}{l}\text { Round, smooth } \\
\text { and raised } \\
\text { colonies with } \\
\text { pinkish colour on } \\
\text { MacConkey agar }\end{array}$ & $\begin{array}{l}\text { Cocci that forms } \\
\text { irregular shaped } \\
\text { clusters and are } \\
\text { non-motile }\end{array}$ & Positive \\
\hline $\begin{array}{l}\text { Klebsiella } \\
\text { species }\end{array}$ & $\begin{array}{l}\text { Round mucoid } \\
\text { colonies on } \\
\text { MacConkey agar }\end{array}$ & $\begin{array}{l}\text { Capsulated rod } \\
\text { shaped organism } \\
\text { that are non-motile }\end{array}$ & Positive \\
\hline $\begin{array}{l}\text { Escherichia } \\
\text { coli }\end{array}$ & $\begin{array}{l}\text { Flat and smooth } \\
\text { colonies } \\
\text { MacConkey }\end{array}$ & $\begin{array}{l}\text { Rod shaped } \\
\text { motile } \\
\text { organism }\end{array}$ & Positive \\
\hline
\end{tabular}




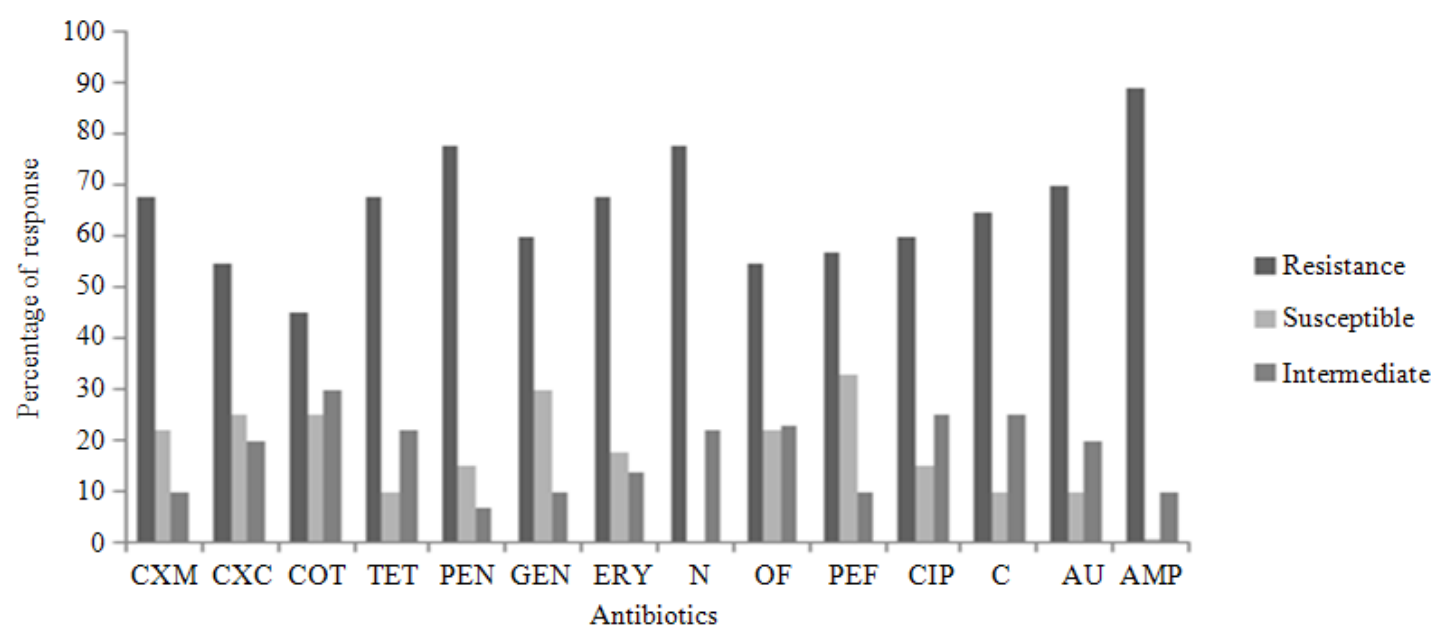

Fig. 1. Antibiotic sensitivity pattern of S. aureus in percentage

Table 2. Biochemical characteristic of the isolates

\begin{tabular}{|c|c|c|c|c|c|c|}
\hline Isolates & Oxidase & Catalase & Citrate & Coagulase & Indole & $\begin{array}{l}\text { Suspected } \\
\text { organisms }\end{array}$ \\
\hline 1 & - & + & - & + & - & $\begin{array}{l}\text { Staphyloco ccus } \\
\text { aureus }\end{array}$ \\
\hline 2 & - & - & + & - & - & $\begin{array}{l}\text { Klebsiella } \\
\text { species }\end{array}$ \\
\hline 3 & - & - & - & - & + & Escherichia colt \\
\hline
\end{tabular}

Table 3. Frequency of bacterial occurrence in ATMs metallic keypads

\begin{tabular}{ll}
\hline Isolates & Keyboards $(\%)$ \\
\hline Staphylococcus aureus & $9(50)$ \\
Klebsiella species & $6(33.3)$ \\
Escherichia coli & $3(16.7)$ \\
Total & $18(100)$ \\
\hline
\end{tabular}

Out of 20 samples analyzed, a total of 18 bacteria isolates were obtained from ATMs metallic keypads. Out of which 9 Staphylococcus aureus, 6 were Klebsiella species and 3 were Escherichia coli as shown in Table 3.

Table 4 shows the antibiotic sensitivity test result of the isolates. The zone of inhibition of the antibiotics was measured in millimeter. The organism responses were sensitive, immediate or resistive to the antibiotics. The table below shows that the organisms developed the highest resistance to penicillin and tetracycline but were susceptible to ciprofloxacin and cotrimoxazole.

Ampicillin showed the highest resistance \% response profile among all the antibiotics tested against $S$. aureus, followed by nalidixic acid and penicillin, while cotrimaxole showed the lowest resistance \% response profile among all the antibiotics tested against $S$. aureus. Peflacine showed the highest susceptible \% response profile among all the antibiotics tested against $S$. aureus, followed by gentamycin and cotrimaxole, while nalidixic acid and ampicillin showed the lowest susceptible \% response profile among all the antibiotics tested against $S$. aureus. Cotrimaxole showed the highest intermediate $\%$ response profile among the entire antibiotics test against $S$. aureus, followed by ceporex and ciprofloxacin, while penicillin showed the lowest intermediate $\%$ response profile among all the antibiotics tested against $S$. aureus (Fig. 1).

Erythromycin showed the highest resistance \% response profile among all the antibiotics tested against Klebsiella species, followed by ampecillin, penicillin and tetracycline, while peflacine and augmentin showed the lowest resistance $\%$ response profile among all the antibiotics tested against Klebsiella species. Cotrimaxole, ciprofloxacine and augmentin showed the highest susceptible \% response profile among all the antibiotics tested against Klebsiella species, while erythromycin, ofloxacine and ampicillin showed the lowest susceptible \% response profile among all the antibiotics tested against Klebsiella species. Peflacine showed the highest intermediate \% response profile among the entire antibiotics test against Klebsiella species, followed by ceporex, cefixime, cloxaciline, peflacine, ciprofloxacin and augmentin, while tetracycline, penicillin and erythromycin showed the lowest intermediate \% response profile among all the antibiotics tested against Klebsiella species (Fig. 2). 
Tetracycline and penicillin showed the highest resistance \% response profile among all the antibiotics tested against Klebsiella species, followed by augmentine, while gentamycin, peflacine and ciprofloxacin showed the lowest resistance \% response profile among all the antibiotics tested against Escherichia coli. Ceporex showed the highest susceptible \% response profile among all the antibiotics tested against Escherichia coli, followed by peflacine and ciprofloxacine, while cotrimaxole, tetracycline, penicillin, erythromycin, nalidixic acid, ofloxacine, augmentine and ampicillin showed the lowest susceptible \% response profile among all the antibiotics tested against Escherichia coli. Ofloxacine showed the highest intermediate \% response profile among the entire antibiotics test against Escherichia coli, while cloxacillin, tetracycline and penicillin showed the lowest intermediate \% response profile among all the antibiotics tested against Escherichia coli (Fig. 3).

Table 4. Antibiotic sensitivity pattern of isolates measure in millimeter

\begin{tabular}{|c|c|c|c|c|c|c|c|c|c|c|c|c|c|c|}
\hline Isolates Code & AMP & CXM & $\mathrm{CXC}$ & COT & TET & PEN & GEN & ERY & $\mathrm{N}$ & OF & $\mathrm{PF}$ & CIP & $\mathrm{C}$ & $\mathrm{AU}$ \\
\hline S. aureus 1 & $\mathrm{R}$ & 16 & $\mathrm{R}$ & 22 & $\mathrm{R}$ & $\mathrm{R}$ & 17 & 13 & $\mathrm{R}$ & $\mathrm{R}$ & $\mathrm{R}$ & $\mathrm{R}$ & $\mathrm{R}$ & $\mathrm{R}$ \\
\hline S. aureus 2 & $\mathrm{R}$ & 12 & 10 & 15 & $\mathrm{R}$ & $\mathrm{R}$ & 2 & 1 & $\mathrm{R}$ & 17 & 18 & 2 & $\mathrm{R}$ & $\mathrm{R}$ \\
\hline S. aureus 3 & 17 & 2 & 18 & 24 & 11 & 10 & 14 & 19 & 20 & 12 & 1 & 20 & 20 & 18 \\
\hline S. aureus 4 & $\mathrm{R}$ & $\mathrm{R}$ & $\mathrm{R}$ & 12 & 10 & 5 & 10 & 10 & $\mathrm{R}$ & $\mathrm{R}$ & $\mathrm{R}$ & 7 & $\mathrm{R}$ & $\mathrm{R}$ \\
\hline S. aureus 5 & 12 & 10 & 13 & $\mathrm{R}$ & $\mathrm{R}$ & 10 & 14 & 12 & $\mathrm{R}$ & $\mathrm{R}$ & 15 & 22 & 18 & 22 \\
\hline S. aureus 6 & $\mathrm{R}$ & 16 & 10 & 11 & $\mathrm{R}$ & 17 & 15 & 16 & 10 & 17 & 15 & 19 & 10 & $\mathrm{R}$ \\
\hline S. aureus 7 & $\mathrm{R}$ & 20 & 18 & 20 & 19 & 18 & 20 & 25 & 20 & 20 & $\mathrm{R}$ & 17 & $\mathrm{R}$ & $\mathrm{R}$ \\
\hline S. aureus 8 & 10 & 10 & 14 & 15 & 17 & 5 & 12 & $\mathrm{R}$ & 10 & 18 & 14 & $\mathrm{R}$ & 14 & 12 \\
\hline S. aureus 9 & 10 & $\mathrm{R}$ & 1 & 17 & 15 & $\mathrm{R}$ & $\mathrm{R}$ & $\mathrm{R}$ & $\mathrm{R}$ & $\mathrm{R}$ & 1 & 5 & 10 & 15 \\
\hline Klebsiella 3 & 12 & $\mathrm{R}$ & $\mathrm{R}$ & 17 & $\mathrm{R}$ & $\mathrm{R}$ & 22 & $\mathrm{R}$ & 15 & 15 & 18 & 22 & 15 & 10 \\
\hline Klebsiella 4 & 10 & 16 & $\mathrm{R}$ & 10 & $\mathrm{R}$ & $\mathrm{R}$ & $\mathrm{R}$ & $\mathrm{R}$ & 17 & 12 & 15 & 16 & 17 & 19 \\
\hline Klebsiella 5 & 10 & 21 & 19 & 22 & 22 & 22 & $\mathrm{R}$ & $\mathrm{R}$ & $\mathrm{R}$ & $\mathrm{R}$ & $\mathrm{R}$ & 19 & 21 & 20 \\
\hline Klebsiella 6 & $\mathrm{R}$ & 15 & 15 & 20 & $\mathrm{R}$ & $\mathrm{R}$ & $\mathrm{R}$ & $\mathrm{R}$ & $\mathrm{R}$ & 15 & 21 & 19 & $\mathrm{R}$ & 20 \\
\hline E. coli 1 & $\mathrm{R}$ & 10 & $\mathrm{R}$ & 14 & $\mathrm{R}$ & $\mathrm{R}$ & 15 & $\mathrm{R}$ & 12 & 15 & 20 & 22 & $\mathrm{R}$ & $\mathrm{R}$ \\
\hline E. coli 2 & $\mathrm{R}$ & 15 & $\mathrm{R}$ & 15 & $\mathrm{R}$ & $\mathrm{R}$ & 15 & $\mathrm{R}$ & 15 & 15 & 13 & 15 & 15 & 10 \\
\hline E. coli 3 & $\mathrm{R}$ & $\mathrm{R}$ & 22 & $\mathrm{R}$ & $\mathrm{R}$ & $\mathrm{R}$ & 25 & 14 & 12 & 10 & 15 & 18 & 21 & 10 \\
\hline
\end{tabular}

Key: $\mathrm{E}$. coli $=$ Escherichia coli, $\mathrm{R}=$ Resistance, $\mathrm{AMP}=$ Ampicillin, $\mathrm{CXM}=$ Cefixime, $\mathrm{CXC}=$ Cloxacillin, $\mathrm{COT}=$ Cotrimoxazole, $\mathrm{TET}=$ Teteracycline $=\mathrm{PEN}=$ Penicillin, $\mathrm{GEN}=$ Gentamycin, $\mathrm{ERY}=$ Erythromycin, $\mathrm{N}=$ Nalidixic acid, $\mathrm{OF}=\mathrm{Tarivid}, \mathrm{PF}=$ Peflacine, CIP

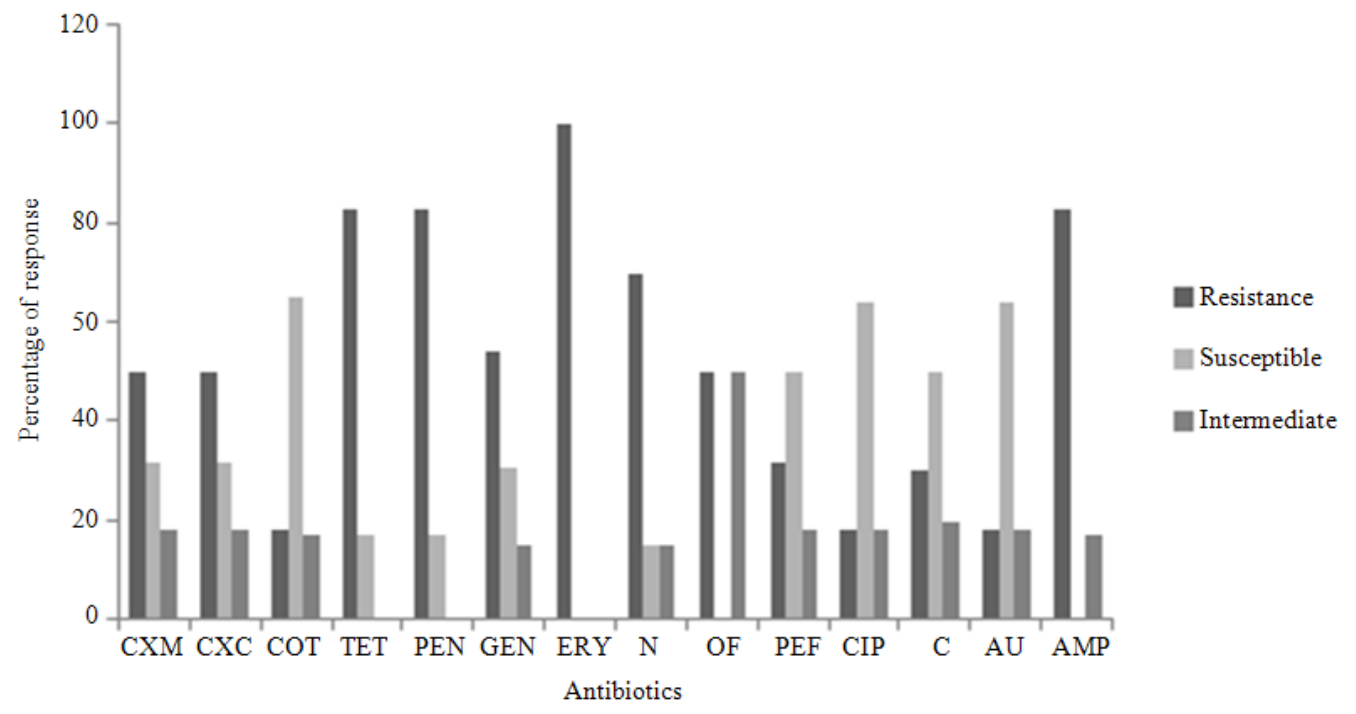

Fig. 2. Antibiotic sensitivity pattern of Klebsiella species in percentage 


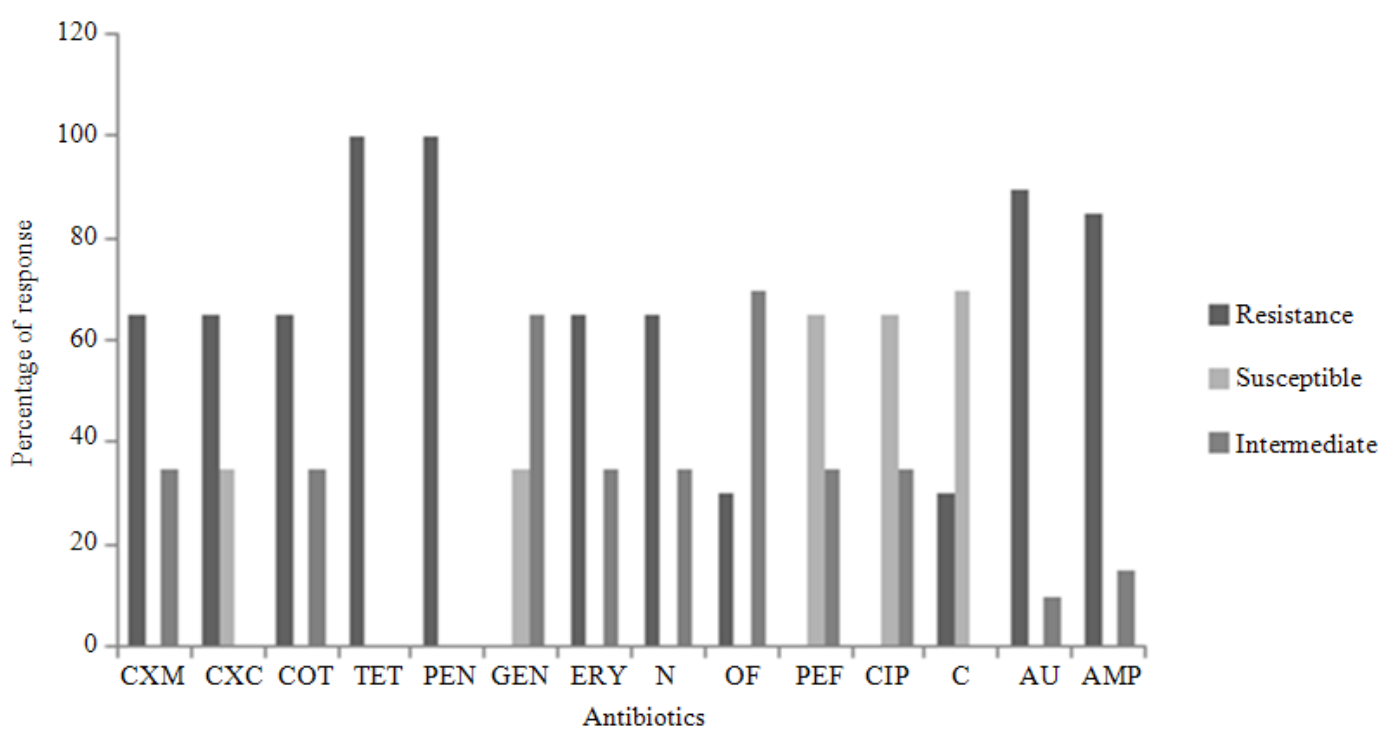

Fig. 3. Antibiotic sensitivity pattern of Escherichia coli species in percentage

\section{DISCUSSION}

The results of this study showed high level of bacterial contaminations of the surfaces of the metallic keypads of ATMs with Staphylococcus aureus, Klebsiella species and Escherichia coli. The number of microorganisms present on a surface is amongst the microbe-associated factors that determine whether an infection will occur or not (Neely and Sittig, 2002). Apart from the quantity of bacteria, the type and quality of microorganism present on a surface is also an important determinant of whether an infection will occur or not (Oluduro et al., 2011).

The high level of bacterial contamination seen in this study is in line with the study of Oluduro et al. (2011), who reported that keypads of ATMs haboured more bacteria than computer keyboards and this may be due to the fact that ATMs are usually located in the open, exposed to wind and rain. This study is also in agreement with the study of Abban and Tano-Debrah (2011) who reported the presence of Staphylococcus species, Escherichia species and Klebsiella species on the keypads of ATM machines. In the same vein, Anastasiades et al. (2009) reported that Staphylococcus aureus are prevalent on computer keyboards and mouse.

The result of this study is of public health concern especially for expatriates residing in Abakaliki Metropolis; Rusin et al. (2002) reported that even low levels of Salmonella spp. and some Escherichia coli strains can easily be transferred from the fingers to food surfaces.

It has been observed that antibiotic susceptibility of bacterial isolates is not constant but dynamic and varies with time and environment (Hassan, 1995). This therefore demands the need for periodic screening of common bacterial pathogens for their antibiotic susceptibility profiles in different communities (Rahman et al., 2007). The antibiogram result of this study showed that Staphylococcus aureus was 89\% resistant to ampicillin, followed by penicillin (78\%), nalidixic acid (78\%), augmentine $(70 \%)$, cefixime $(68 \%)$, tetracycline $(68 \%)$, erythromycin $(68 \%)$, ceporex $(65 \%)$, gentamycine (60\%), ciprofloxacin $(60 \%)$, peflacin $(57 \%)$, cloxacilline $(55 \%)$ and tarivid (55\%), while $33 \%$ and $30 \%$ were susceptible to peflacine and gentamycin respectively. This is an indication that the $S$. aureus isolated were multiple drug resistance. All most all the antibiotics tested were resistance to $S$. aureus. This result agrees with the result of the study carried out at Cape Town, Ghana by Tagoe and Kumi-Ansah (2011) where Staphylococcus aureus was $83 \%$ resistant to ampicillin, penicillin and nalidixic. In the same vein Oluduro et al. (2011) reported that $S$. aureus resistance to 2 antibiotics was the commonest multiple antibiotic resistance patterns observed, while resistance to a combination of 3 antibiotics was also prevalent. Klebsiella species were $100 \%$ resistant to erythromycin, followed by tetracycline (83\%), penicillin $(83 \%)$, ampicillin (83\%), nalidixic acid $(70 \%)$, gentamycine $(54 \%)$ cefixime $(50 \%)$, cloxacilline $(50 \%)$ and tarivid 
(50), but showed high level susceptibility to cotrimoxazole $(65 \%)$, followed by ciproflocacin $(64 \%)$, augmentine (64\%), peflacine (50\%) and ceporex (50\%). Escherichia coli were $100 \%$ resistant to tetracycline and penicillin, followed by augmentine $(90 \%)$, ampicilin (85\%), cefixime $(65 \%)$, cloxacilline $(65 \%)$, cotrimoxazole $(65 \%)$, erythromycin $(65 \%)$ and nalidixic acid $(65 \%)$, but $70 \%$ susceptible to ceporex, followed by peflacine $(65 \%)$ and ciprofloxacin $(65 \%)$. This study is similar to the study of Issmat et al. (2007) who isolated multi-drug resistant bacteria from public interfaces (computer surfaces). Occurrence of resistance in pathogens may reduce the effectiveness of previously useful antibiotics (Toroglu and Dincer, 2008). This study disagrees with the result of the antibiogram data obtained by Oluduro et al. (2011) where the susceptibility of Escherichia coli to erythromycin and ciproflox was 93\% and $35 \%$ respectively. The variation in the result might be because of variation in geographical locations, environmental conditions and genetic background of the organism and the abuse of drugs in a location which leads to drug resistance (Anupurba et al., 2006).

\section{CONCLUSION}

This study confirmed the presence of bacterial contamination on ATM metallic keypads. The organism isolated were Staphylococcus aureus, Escherichia coli, Klebsiella species and a coagulase negative Staphylococcus aureus. The result of the antibiotic test showed that cotrimoxazole, ciprofloxacin and augmentine are drugs of choice for Klebsiella. Also, ceporex, peflacine and ciprofloxacin showed to be the drugs of choice for Escherichia coli. Indeed, has demonstrated that microbial contamination of ATM keypads may be a common mechanism of transfer of potentially pathogenic bacteria, among users.

\section{REFERENCES}

Abban, S. and K. Tano-Debrah, 2011. Automatic Teller Machines (ATMs) as potential sources of foodborne pathogens-a case from Ghana. Nature Sci., 9: 63-67.

Anastasiades, P., T.L. Pratt, L.H. Rousseau, W.H. Steinberg and G. Joubert, 2009. Staphylococcus aureus on computer mice and keyboards in intensive care units of the Universitas Academic Hospital, Bloemfontein and ICU staff's knowledge of its hazards and cleaning practices. South Afr. J. Epidemiol. Infect., 24: 22-26.
Anupurba, S., A. Bhattacharjee, A. Garg and D.R. Sen, 2006. Antimicrobial susceptibility of pseudomonas aeruginosa isolated from wound infections. Indian J. Dermatol., 51: 286-288. DOI: 10.4103/00195154.30298

Cheesbrough, M., 2006. District Laboratory Practice in Tropical Countries. 2nd Edn., Cambridge University Press, Cambridge, ISBN-10: 113944929X, pp: 440.

Famurewa, O. and O.M. David, 2009. Cell Phone: A medium of transmission of bacterial pathogens. World Rural Observat., 1: 69-72.

Filho, P.P.G., M. Stumpf and C.L. Cardoso, 1987. Survival of gram-negative and gram-positive bacteria artificially applied on the hands. J. Clin. Microbiol., 23: 552-553. PMID: 3988907

Fraser, M.A. and S.J. Girling, 2009. Bacterial carriage of computer keyboards in veterinary practices in Scotland. Vet. Rec., 165: 26-27. PMID: 19578192

French, G.L., J.A. Otterb, K.P. Shannona, N.M.T. Adamsb and D. Watlingb et al., 2004. Tackling contamination of the hospital environment by Methicillin-Resistant Staphylococcus aureus (MRSA): A comparison between conventional terminal cleaning and hydrogen peroxide vapour decontamination. J. Hosp. Infect., 57: 31-37. DOI: 10.1016/j.jhin.2004.03.006

Gerba, C.P., 2005. Importance of fomites in the transmission of infectious disease. University of Arizona.

Gholamreza, S., T. Nooshin, M. Ali, M.S. Touraj-Reza and S. Ehsan, 2009. Bacterial contamination and resistance to commonly used antimicrobials of healthcare workers' mobile phones in teaching hospitals, Kerman, Iran. Am. J. Applied Sci., 6: 806810.

Hardy, K.J., B.A. Oppenheim, S. Gossain, F. Gao and P.M. Hawkey, 2006. A study of the relationship between environmental contamination with Methicillin-Resistant Staphylococcus Aureus (MRSA) and patients' acquisition of MRSA. Infect Control Hosp. Epidemiol., 27: 127-132. PMID: 16465628

Hassan, S.H., 1995. Sensitivity of Salmonella and Shigella to antibiotics and chemotherapeutic agents in Sudan. J. Trop. Med. Hyg., 88: 243-248. PMID: 3853591

Hood, S.K. and E.A. Zottola, 1997. Adherence to stainless steel by foodborne microorganisms during growth in model food systems. Int. J. Food Microbiol., 37: 145-153. DOI: 10.1016/S01681605(97)00071-8 
Humphrey, T.J., K.W. Martin and A. Whitehead, 1994. Contamination of hands and work surfaces with Salmonella enteritidis PT4 during the preparation of egg dishes. Epidemiol. Infect., 113: 403-409. DOI: 10.1017/S0950268800068412

Issmat, I.K., S. Von and A.E. Malak, 2007. Public computer surfaces are reservoirs for methicillinresistant staphylococci. Int. Soc. Microbiol. Ecol. J., 1: 265-268. DOI: 10.1038/ismej.2007.36

Kissiedu, K.O., 2002. Evaluation of currency note as agents of microbial cross contamination. BSc. Thesis, Dissertation, University of Ghana, Legon, Ghana.

NCCLS, 2000. Performance Standard for Antimicrobial Disk Susceptibility Tests; Approved Standards. 9th Edn., NCCLS, ISBN-10: 1562383930, pp: 26.

Neely, A.N. and D.F. Sittig, 2002. Basic microbiologic and infection control information to reduce the potential transmission of pathogens to patients via computer hardware. J. Am. Med. Inform. Assoc., 9: 500-508. PMID: 12223502

Neely, A.N. and M.P. Maley, 2000. Survival of Enterococci and Staphylococci on hospital fabrics and plastic. J. Clin. Microbiol., 38: 724-726. PMID: 10655374

Oluduro, A.O., A.O. Ubani and I.E. Ofoezie, 2011. Bacterial assessment of electronic hardware user interfaces in Ile-Ife, Nigeria. J. Basic Applied Pharmaceut. Sci., 32: 323-334.

Rahman, M., B. Rahman, T. Rahman, F.R. Khan and M.J. Hosen et al., 2007. Patterns of antimicrobial resistance and plasmid profiles of Escherichia coli isolates obtained from calf, cattle and diarrheic children in Mymensingh-Bangladesh. J. Am. Sci., 3: 74-84.
Rasiah, D., 2010. ATM risk management and controls. Eur. J. Econ. Finance Admin. Sci., 1: 161-171.

Rusin, P., S. Maxwell and C. Gerba, 2002. Comparative surface-to-hand and fingertip-to-mouth transfer efficiency of gram-positive bacteria, gram-negative bacteria and phage. J. Applied Microbiol., 3: 585592. PMID: 12234341

Sharma, M. and S.K. Anand, 2002. Biofilms evaluation as an essential component of HACCP for food/dairy processing industry-a case. Food Control, 13: 469477. DOI: 10.1016/S0956-7135(01)00068-8

Tagoe, D.N.A. and F. Kumi-Ansah, 2011. Computer keyboard and mice: Potential sources of disease transmission and infections. Int. J. Public Health. DOI: $10.5580 / \mathrm{a} 19$

Toroglu, S. and S. Dincer, 2008. Elimination and conjugal transfer of their resistance in isolated gram negative bacteria from Aksu River (Kahramanmaras-Turkey). Adv. Environ. Biol., 2: 124-131.

Ulger, F., S. Esen, A. Dilek, K. Yanik and M. Gunaydin, et al., 2009. Are we aware how contaminated our mobile phones with nosocomial pathogens? Ann. Clin. Microbiol. Antimicrob., 8: 1-4. DOI: 10.1186/1476-0711-8-7 